\title{
Metformin and lung cancer risk of patients with type 2 diabetes mellitus: A meta-analysis
}

\author{
NING ZHU*, YUANYUAN ZHANG* ${ }^{*}$ YI GONG, JIAN HE and XIAODONG CHEN \\ Respiratory Department, Huashan Hospital, Affiliated to Fudan University, Shanghai 200040, P.R. China
}

Received November 20, 2014; Accepted November 28, 2014

DOI: 10.3892/br.2015.417

\begin{abstract}
The association between metformin and the lung cancer risk of patients with type 2 diabetes mellitus (T2DM) remains controversial. Therefore, the present meta-analysis on epidemiological studies was performed to explore this issue. A comprehensive literature search was conducted for all the potential studies addressing metformin use and lung cancer risk by utilizing Pubmed, CBM and ISI Web of Science using the Mesh terms: 'Metformin,' or 'biguanides' and 'lung cancer,' or 'neoplasms'. The reference lists were also inspected. Eight observational studies, including 17,997 lung cancer patients, were eventually selected, which contained seven case-control and one cohort study. Compared to other antidiabetic agents, metformin was significantly associated with the $16 \%$ reduction of lung cancer risk in type 2 diabetic patients [relative risk $(\mathrm{RR})=0.84 ; 95 \%$ confidence interval $(95 \% \mathrm{CI}), 0.73-0.97]$. In the sensitivity analysis by separately excluding the study with a high weight or lower quality, the results did not materially change. Subsequently, subgroup analysis was performed on the type of study design, unadjusted or adjusted hazard ratio, quality of enrolled studies, duration of treatment, country and control drugs. The magnitude of lung cancer risk reduction was strengthened when compared to sulfonylureas ( $\mathrm{RR}=0.79 ; 95 \% \mathrm{CI}, 0.83-0.9)$, without significant heterogeneity ( $\mathrm{Q}$-value $=2.98, \mathrm{P}=0.085)$. In conclusion, the present analysis supported that the use of metformin significantly decreased the risk of lung cancer among patients with T2DM. However, further studies are required to confirm these findings.
\end{abstract}

Correspondence to: Mr. Xiaodong Chen, Respiratory Department, Huashan Hospital, Affiliated to Fudan University, 12 Wulumuqi Middle Road, Shanghai 200040, P.R. China

E-mail: xdchen8@hotmail.com

*Contributed equally

Key words: metformin, type 2 diabetes mellitus, lung cancer, risk, meta-analysis

\section{Introduction}

Diabetic mellitus is a worldwide common metabolic disease. Abundant evidence indicated that diabetic mellitus was associated not only with cardiovascular diseases, nephropathy and retinopathy, but also with the development of numerous types of cancer, including lung, liver, colorectal, kidney and breast (1-4). By contrast, hyperglycemia appears to be a protective factor for prostate cancer (5).

Glucose lowering drugs are possibly associated with either an increased or reduced risk of cancer (6). Metformin is an commonly used oral agent for treating patients with type 2 diabetes mellitus (T2DM) and may be safely used in combination with other antidiabetic agents. Two different ways by which metformin exerts anti-neoplastic effects include: i) Activating adenosine monophosphate-activated protein kinase (AMPK) by the liver kinase B1; and ii) inhibition of protein synthesis. Tumor cells establish mechanisms to downregulate AMPK, allowing them to escape its restraining influences on growth. However, metformin can act as a tumor growth inhibitor by upregulating AMPK and suppressing the mammalian target of rapamycin, leading to reduced protein synthesis in cancer cells (7-9). In addition, metformin also induces activation of the immune system, cell arrest or apoptosis and reduces growth factor signaling (10).

Previous studies have confirmed that metformin inhibits tumor cell proliferation and improves the survival of cancer patients (11-15). A meta-analysis has been performed to evaluate the association between metformin and cancer risk in diabetic patients, which found that metformin has a preventive effect on cancer incidence and mortality (16). One study conducted in Taiwan found that metformin reduced the incidences of several gastroenterological cancers in treated diabetes (17).

Lung cancer has become one of the leading causes of cancer-related mortality in numerous countries. Recent data have suggested an association of metformin use with decreased lung cancer risk of type 2 diabetic patients (18-20). Mazzone et al (18) found that the use of metformin is associated with a lower likelihood of developing lung cancer in diabetic patients, which was coherent with the study by Lai et al (20). By contrast, the study by Bodmer et al (21) obtained the opposite result. Another observational study by Smiechowski et al (22) demonstrated that metformin use was not associated with a decreased risk of lung cancer in patients with T2DM. Thus, the 
results remain controversial and the present meta-analysis was performed to investigate the association between metformin use and lung cancer risk of individuals with T2DM.

\section{Materials and methods}

Search strategy. A comprehensive literature search was performed for all the studies addressing the association between metformin use and lung cancer risk. Electronic databases searched included Pubmed, CBM and ISI Web of Science until October 2013, without language restrictions. The Mesh terms and/or the text words used included 'metformin' or 'biguanides' and lung 'cancer' or 'neoplasms'. In addition, the reference lists were also inspected.

Selection criteria. The inclusion criteria of a study in the meta-analysis included the following: i) Epidemiological studies, which included case-control or cohort studies; ii) designed to evaluate the association between metformin and risk of lung cancer in diabetic patients; and iii) contained sufficient information to allow adequate estimation of hazard ratio (HR), odds ratio (OR), or relative risk (RR) and 95\% confidence interval $(95 \% \mathrm{CI})$ to estimate the lung cancer risk with diabetes using metformin compared to other antidiabetic treatments or no treatment. When two independent control groups were set in the same case-control study, the study was treated as two separate studies, only considering the limited relevant studies enrolled.

Data extraction and quality assessment. The enrolled studies were evaluated by two independent authors (Ning Zhu and Yuanyuan Zhang). For the included studies, these data were extracted: First author, year of publication, country or area, study design, source of cases, number of total participants or lung cancer cases, study time or follow-up time, unadjusted and adjusted RR with their 95\% CIs and the confounding factors, which had been adjusted. To ascertain the validity of the eligible studies, the quality of each study was appraised in reference to the Newcastle-Ottawa statement (23). In this 'star system' scale, studies were judged on three aspects: Selection, comparability and exposure. For the selection and exposure categories, a maximum of one star was awarded for each numbered item, whereas for the comparability, a maximum of two stars was awarded. Therefore, the quality of each study, with nine stars at most ,was classified as follows: $\leq 5$ stars as low quality and $\geq 6$ stars as high quality. Disagreements were resolved by discussion between the two investigators. When required, another investigator (Xiaodong Chen) was consulted to resolve the dispute.

Statistical analyses. The value of RR was adopted for the cohort studies or OR for the case-control studies to evaluate the risk estimate in the meta-analysis. When the adjusted RRs were available, they were used to estimate the association. Otherwise, the unadjusted RRs were adopted. The adjusted HR was pooled using the DerSimonian and Laird statistic. Stratified analyses were conducted according to type of study design, type of HRs, study quality, country, duration of treatment or control drugs. Studies were pooled and weighted according to inverse variance using the random-effects model of DerSimonian and Laird. $\mathrm{P}<0.05$ was considered to indicate a statistically significant difference for all the tests. Sensitivity analysis was conducted by sequentially excluding one study with a high weight or low quality. Finally, the publication bias was detected using the Begg's funnel plot and Egger's regression asymmetry test. All analyses were performed using Stata version 11.0 (StataCorp, College Station, TX, USA).

\section{Results}

Search results. The participant flow diagram for the study inclusion in the meta-analysis is shown in Fig. 1. Eight studies, including 17,997 lung cancer patients, were finally enrolled into the meta-analysis, which contained seven case-control $(18-22,24,25)$ and one cohort study (26). The general information regarding the studies, including author, year, type of study design, source of case, duration of observation, number of cases, matched factor, adjusted or unadjusted HR and study quality, are presented in the Table I.

These studies were conducted in six countries, which were Canada (22), the Netherlands (19), Switzerland (21), Scotland (UK) (26), Taiwan (China) $(20,24,25)$ and USA (18). Three studies were conducted in Asian countries and five studies in Western countries. One case-control study, performed in Taiwan by Hsieh et al (24), separately compared insulin or sulfonylureas with metformin for the effect on lung cancer risk of patients with T2DM. Considering these two independent antidiabetic agents and the limited enrolled studies, this study was treated as two independent case-control studies in the meta-analysis. Only two studies evaluated the effect of metformin on the lung cancer risk of patients with T2DM by comparing to sulfonylureas $(19,24)$.

Overall analysis. The baseline characteristics of these enrolled studies are demonstrated in Table I. The adjusted RR was derived from all the eight studies. Compared to other antidiabetic agents, metformin was significantly associated with a $16 \%$ reduction of lung cancer risk in type 2 diabetic patients ( $\mathrm{RR}=0.84$; 95\% CI, 0.73-0.97; $\mathrm{P}=0.019$ ). As significant heterogeneity existed among these studies (Q-value $=22.10$, $\mathrm{P}=0.005$ ), the random-effects model was used. In order to confirm the validity and stability of the results, a study with high weight (19) or low quality (25) was separately excluded in the sensitivity analysis and consistent results were observed ( $\mathrm{RR}=0.81$; 95\% CI, 0.65-0.99; and $\mathrm{RR}=0.74$; 95\% CI, 0.62-0.89). The forest plot is shown in Fig. 2.

Subgroup analysis. In order to validate the results of the overall analysis and find the possible source of statistical heterogeneity among studies, the subgroup analysis was performed. As mentioned above, subgroup analysis was conducted according to several different variables, which are shown in Table II.

A statistically significant reduction of the lung cancer risk in type 2 diabetic patients using metformin was obtained when the studies were restricted to case-control studies or studies with high quality ( $\mathrm{RR}=0.85 ; 95 \% \mathrm{CI}, 0.73-0.99$; and $\mathrm{RR}=0.74 ; 95 \% \mathrm{CI}, 0.62-0.89$ ), which were consistent with the result of the overall analysis. In the subgroup analysis regarding the unadjusted HR $(20,21,26)$, no significant association was found between metformin use and the lung cancer 
Table I. Baseline characteristics of the included studies.

\begin{tabular}{|c|c|c|c|c|c|c|c|c|c|c|c|c|}
\hline \multirow{2}{*}{$\begin{array}{l}\text { First } \\
\text { author } \\
\text { (year) }\end{array}$} & \multirow[b]{2}{*}{ Country } & \multirow{2}{*}{$\begin{array}{l}\text { Study } \\
\text { design }\end{array}$} & \multirow{2}{*}{$\begin{array}{c}\text { Duration of } \\
\text { observation, } \\
\text { years }\end{array}$} & \multirow{2}{*}{$\begin{array}{l}\text { No. of } \\
\text { metformin } \\
\text { users (lung } \\
\text { cancer } \\
\text { patients) }\end{array}$} & \multirow{2}{*}{$\begin{array}{l}\text { Source } \\
\text { of case }\end{array}$} & \multirow[b]{2}{*}{ Matched factor } & \multicolumn{2}{|c|}{ Unadjusted } & \multicolumn{2}{|c|}{ Adjusted } & \multirow{2}{*}{$\begin{array}{c}\text { Study } \\
\text { quality }^{\mathrm{a}}\end{array}$} & \multirow[b]{2}{*}{ (Refs.) } \\
\hline & & & & & & & HR & $95 \% \mathrm{CI}$ & HR & $95 \% \mathrm{CI}$ & & \\
\hline $\begin{array}{l}\text { Wang } \\
(2013)\end{array}$ & Taiwan & Cohort & 1998-2009 & $\begin{array}{c}37,055 \\
(162)\end{array}$ & $\begin{array}{l}\text { National Health } \\
\text { Insurance } \\
\text { datasets }\end{array}$ & $\begin{array}{l}\text { Age, gender } \\
\text { and occupation }\end{array}$ & NA & NA & 1.11 & $0.94-1.47$ & 4 & (25) \\
\hline $\begin{array}{l}\text { Smiechowski } \\
\text { (2013) }\end{array}$ & Canada & $\begin{array}{l}\text { Nested } \\
\text { case- } \\
\text { control }\end{array}$ & $\begin{array}{c}\text { Mean } \\
\text { follow-up, } \\
5.6\end{array}$ & $\begin{array}{c}115,923 \\
(1,061)\end{array}$ & $\begin{array}{l}\text { UK General } \\
\text { Practice } \\
\text { Research } \\
\text { Database }\end{array}$ & $\begin{array}{l}\text { Age, gender, } \\
\text { calender time } \\
\text { of cohort entry, } \\
\text { duration of } \\
\text { follow-up }\end{array}$ & 0.97 & NA & 0.94 & $0.76-1.17$ & 7 & (22) \\
\hline $\begin{array}{l}\text { Lai } \\
(2012)\end{array}$ & Taiwan & $\begin{array}{l}\text { Retro- } \\
\text { spective } \\
\text { case- } \\
\text { control }\end{array}$ & $2000-2008$ & $\begin{array}{c}19,624 \\
(96)\end{array}$ & $\begin{array}{l}\text { National Health } \\
\text { Research } \\
\text { Institutes } \\
\text { in Taiwan }\end{array}$ & Age, gender & 0.43 & $0.29-0.63$ & 0.55 & $0.37-0.82$ & 7 & (20) \\
\hline $\begin{array}{l}\operatorname{Hsieh}^{\mathrm{b}}(\mathrm{a}) \\
(2012)\end{array}$ & Taiwan & $\begin{array}{l}\text { Case- } \\
\text { control }\end{array}$ & $2000-2008$ & $\begin{array}{c}3,963 \\
(1,226)\end{array}$ & $\begin{array}{l}\text { Taiwan's } \\
\text { National Health } \\
\text { Insurance } \\
\text { Medical Claims } \\
\text { Database }\end{array}$ & Age, gender & NA & NA & 0.95 & $0.46-1.95$ & 6 & (24) \\
\hline $\begin{array}{l}\operatorname{Hsieh}^{\mathrm{b}}(\mathrm{b}) \\
(2012)\end{array}$ & Taiwan & $\begin{array}{l}\text { Case- } \\
\text { control }\end{array}$ & $2000-2008$ & $\begin{array}{c}3,963 \\
(1,226)\end{array}$ & $\begin{array}{l}\text { Taiwan's } \\
\text { National Health } \\
\text { Insurance } \\
\text { Medical Claims } \\
\text { Database }\end{array}$ & Age, gender & NA & NA & 0.64 & $0.45-0.9$ & 6 & (24) \\
\hline $\begin{array}{l}\text { Mazzone } \\
(2012)\end{array}$ & USA & $\begin{array}{l}\text { Retro- } \\
\text { spective } \\
\text { case- } \\
\text { control }\end{array}$ & 2001-2011 & $\begin{array}{c}93,939 \\
(522)\end{array}$ & $\begin{array}{l}\text { Cleveland } \\
\text { Clinic Health } \\
\text { System }\end{array}$ & $\begin{array}{l}\text { Age, gender, } \\
\text { smoking } \\
\text { history }\end{array}$ & NA & NA & 0.48 & $0.28-0.81$ & 6 & (18) \\
\hline $\begin{array}{l}\text { Ruiter } \\
\text { (2012) }\end{array}$ & $\begin{array}{l}\text { The } \\
\text { Nether- } \\
\text { lands }\end{array}$ & $\begin{array}{l}\text { Case- } \\
\text { control }\end{array}$ & 1998-2008 & $\begin{array}{l}85,289 \\
(1,590)\end{array}$ & $\begin{array}{l}\text { PHARMO } \\
\text { Record } \\
\text { Linkage } \\
\text { System }\end{array}$ & $\begin{array}{l}\text { Age, gender, } \\
\text { calendar time, } \\
\text { no. of unique } \\
\text { drugs used } \\
\text { and no. of } \\
\text { hospitalizations }\end{array}$ & NA & NA & 0.87 & $0.84-0.91$ & 6 & (19) \\
\hline $\begin{array}{l}\text { Bodmer } \\
(2012)\end{array}$ & $\begin{array}{l}\text { Switzer- } \\
\text { land }\end{array}$ & $\begin{array}{l}\text { Case- } \\
\text { control }\end{array}$ & 1995-2009 & $\begin{array}{c}\text { NA } \\
(13,043)\end{array}$ & $\begin{array}{l}\text { UK-based } \\
\text { General } \\
\text { Practice } \\
\text { Research } \\
\text { Database }\end{array}$ & $\begin{array}{l}\text { Age, gender, } \\
\text { general practice, } \\
\text { same index } \\
\text { date and no. } \\
\text { of years of } \\
\text { active history }\end{array}$ & 1.07 & $0.87-1.31$ & 1.09 & $0.85-1.38$ & 6 & (21) \\
\hline $\begin{array}{l}\text { Libby } \\
(2009)\end{array}$ & Scotland & Cohort & 1993-2003 & $\begin{array}{l}4,085 \\
(297)\end{array}$ & $\begin{array}{l}\text { Resident } \\
\text { Population } \\
\text { of Tayside } \\
\text { Health Board } \\
\text { (Scotland, UK) }\end{array}$ & $\begin{array}{l}\text { Age, gender, } \\
\text { BMI, HbA1c, } \\
\text { smoking, } \\
\text { deprivation, } \\
\text { other drug use }\end{array}$ & 0.49 & $0.32-0.74$ & 0.7 & $0.43-1.15$ & 6 & (26) \\
\hline
\end{tabular}

${ }^{a}$ Newcastle-Ottawa star. ${ }^{b}$ The study has separately compared (a) insulin or (b) sulfonylureas with metformin for the effect on lung cancer risk of type 2 diabetic patients. Considering these two independent antidiabetic agents and the limited enrolled studies, this study was treated as two independent case-control studies in the meta-analysis. HR, hazard ratio; 95\% CI, 95\% confidence interval; NA, not available; BMI, body mass index; HbA1c, hemoglobin A1c.

risk of patients with $\mathrm{T} 2 \mathrm{DM}(\mathrm{RR}=0.62 ; 95 \% \mathrm{CI}, 0.33-1.18)$. When stratified by country, it was suggested that metformin use was not significantly associated with the reduction of lung cancer risk in type 2 diabetic patients in Western or Asian countries $(\mathrm{RR}=0.87$; 95\% CI, 0.75-1.02; and $\mathrm{RR}=0.78$; 95\% CI, 0.53-1.15). Regarding long-term use of metformin, a 
Table II. Results of the subgroup analysis according to different variables.

\begin{tabular}{|c|c|c|c|c|c|c|}
\hline \multirow[b]{2}{*}{ Subgroup } & \multirow{2}{*}{$\begin{array}{l}\text { No. of } \\
\text { studies }\end{array}$} & \multirow[b]{2}{*}{ Model } & \multicolumn{2}{|c|}{ Pooled RR } & \multicolumn{2}{|c|}{ Heterogeneity } \\
\hline & & & $\mathrm{RR}(95 \% \mathrm{CI})$ & P-value & Q-value & P-value \\
\hline \multicolumn{7}{|l|}{ Type of design of studies } \\
\hline Case-control & 8 & Random & $0.85(0.73-0.99)$ & 0.04 & 21.32 & 0.003 \\
\hline \multicolumn{7}{|l|}{ Quality of enrolled study } \\
\hline High & 8 & Random & $0.74(0.62-0.89)$ & 0.001 & 29.91 & $<0.001$ \\
\hline \multicolumn{7}{|l|}{ Unadjusted or adjusted HR } \\
\hline Adjusted & 9 & Random & $0.84(0.73-0.97)$ & 0.02 & 22.10 & 0.005 \\
\hline Unadjusted & 3 & Random & $0.62(0.33-1.18)$ & 0.15 & 22.85 & $<0.001$ \\
\hline \multicolumn{7}{|l|}{ Country } \\
\hline Western & 5 & Random & $0.87(0.75-1.02)$ & 0.09 & 9.35 & 0.053 \\
\hline Asian & 4 & Random & $0.78(0.53-1.15)$ & 0.21 & 12.72 & 0.005 \\
\hline \multicolumn{7}{|l|}{ Duration of treatment } \\
\hline Long-term use ${ }^{\mathrm{a}}$ & 4 & Random & $0.89(0.79-1.01)$ & 0.36 & 11.77 & 0.008 \\
\hline \multicolumn{7}{|l|}{ Control drugs } \\
\hline Control groups use sulfonylureas & 2 & Fixed & $0.79(0.83-0.9)$ & 0.000 & 2.98 & 0.085 \\
\hline
\end{tabular}

${ }^{a}$ Lai et al (20), >3 years; Bodmer et al (21), >40 prescriptions; Ruiter et al (19), >1 year; Smiechowski et al (22), >1,485 days. RR, relative risk; 95\% CI, 95\% confidence interval; HR, hazard ratio.

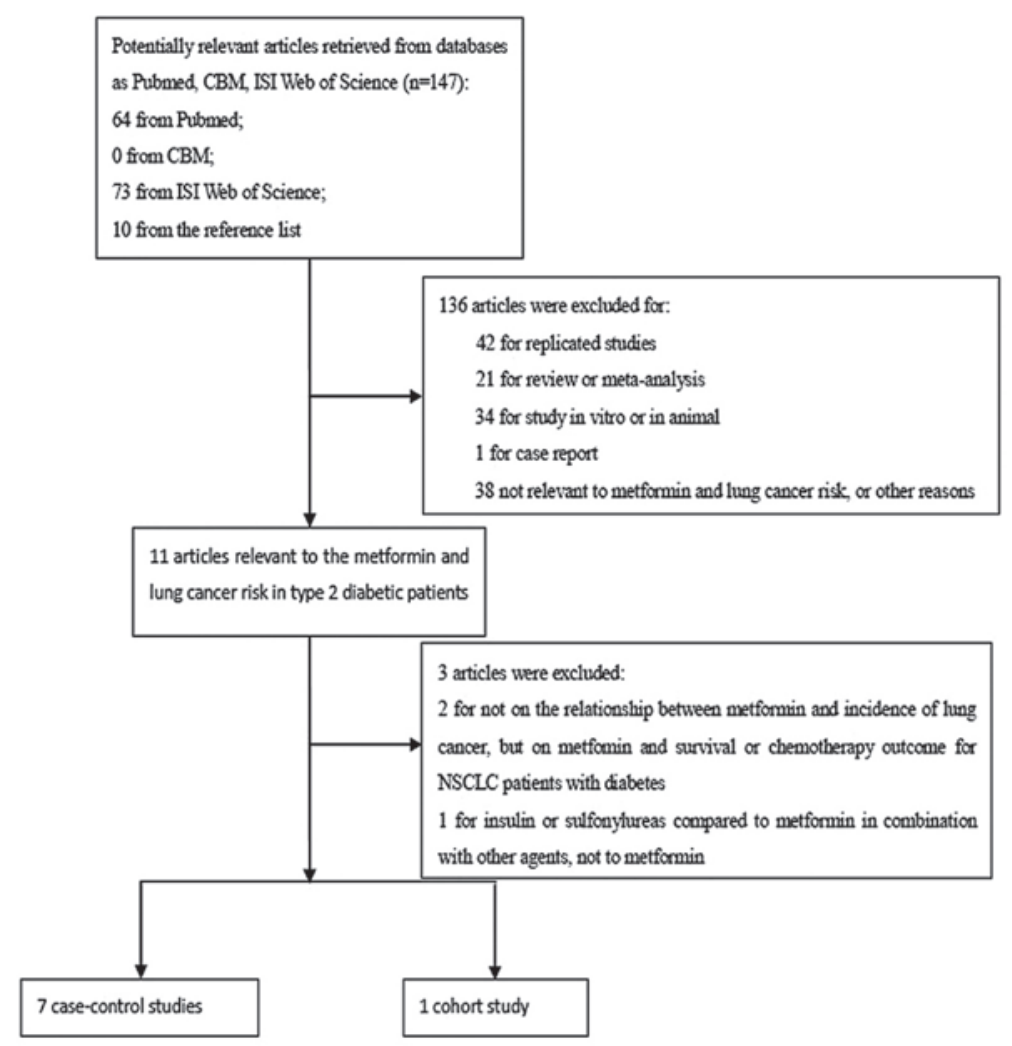

Figure 1. Flow diagram of the study selection. NSCLC, non-small cell lung cancer.

null result was found $(\mathrm{RR}=0.89 ; 95 \% \mathrm{CI}, 0.79-1.01)$. In addition, when compared to sulfonylureas, the use of metformin decreased the lung cancer risk of type 2 diabetic patients ( $R R=0.79$; 95\% CI, 0.83-0.9), without significant heterogeneity $(\mathrm{Q}$-value $=2.98, \mathrm{P}=0.085)$.
Publication bias. As shown in Fig. 3, the publication bias was assessed for the included studies using the Begg's funnel plot and Egger's regression asymmetry test. No significant risk of publication bias was observed by Begg's $(\mathrm{Z}=-1.04, \mathrm{P}=0.3)$ and Egger's test $(\mathrm{t}=-0.59, \mathrm{P}=0.572)$. 

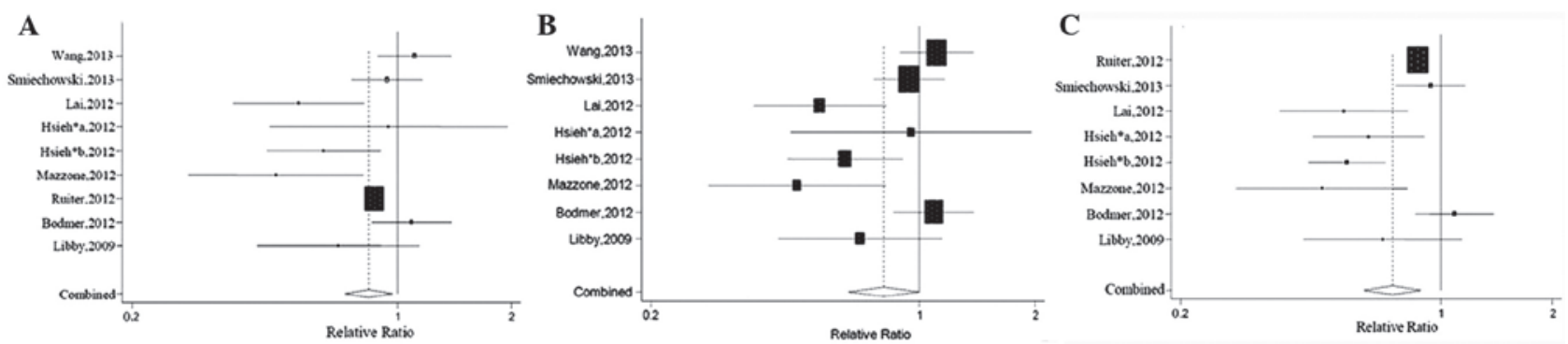

Figure 2. Forest funnel of the pooled relative risks for metformin treatment and lung cancer risk in diabetic patients. (A) Overall analysis. (B and C) Sensitivity analysis excluding one study with a high weight or lower quality, respectively.

A

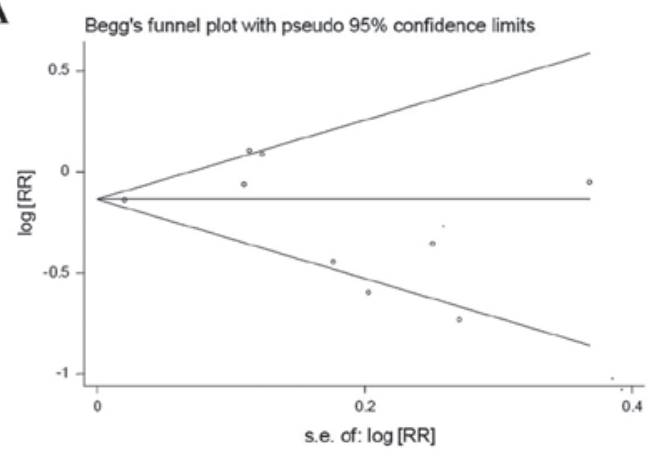

B

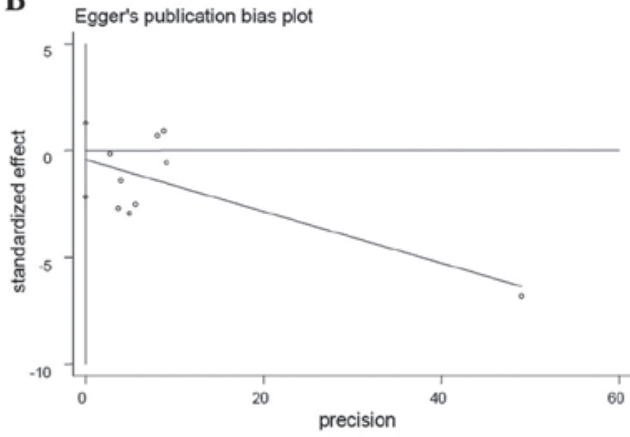

Figure 3. Publications bias detected by (A) Begg's funnel plot and (B) Egger's funnel plot. s.e., standard error; RR, relative risk.

\section{Discussion}

Increasing evidence has strengthened that hyperglycemia, obesity-related insulin resistance and secondary hyperinsulinemia are important regulators of the development of cancer (27-30). Recent data have suggested that insulin and insulin secretagogues (sulfonylureas and glinides) may increase the overall cancer incidence $(21,31,32)$, but insulin sensitizers (metformin and thiazolidinedione) are associated with the reduction of the cancer incidence $(33,34)$. Metformin improved insulin resistance and alleviated the circulating insulin levels, which may be the major reason to decrease the cancer risk in diabetic patients. Within the past years, several studies and meta-analyses have focused on the association between metformin and the reduction of lung cancer risk in patients with T2DM, but the controversy remains among the results, which raise the necessity to resolve this dispute. One previous meta-analysis by Noto et al (16), which included three studies, confirmed the association between metformin use and the reduction of the lung cancer risk among patients with $\mathrm{T} 2 \mathrm{DM}(\mathrm{RR}=0.67,95 \% \mathrm{CI}, 0.45-0.99)$, which was contradictory to that of another meta-analysis based on four observational studies (RR=0.83, 95\% CI, 0.64-1.06) (6). However, these meta-analyses may be affected by possible publication bias due to the few studies enrolled. Therefore, the present study selected and analyzed all the available observational studies to reconfirm the association in the meta-analysis. Eight retrospective studies, including seven case-control and one cohort study, were eventually selected. The majority of them obtainied a high assessment score according to the Newcastle-Ottawa statement, with the exception of one study by Wang et al (25), which was due to lack of detailed information. A significant $52 \%$ reduction was noted in one study conducted in the USA $(\mathrm{RR}=0.48,95 \% \mathrm{CI}, 0.28-0.81)$ (18).

In the present meta-analysis, metformin therapy for type 2 diabetes patients was demonstrated to decrease the lung cancer incidence, compared to other antidiabetic agents. This result was comparable to that of a previously published meta-analysis by Noto et al (16). The major strength of the present meta-analysis was the large number of studies and patients included, which may provide the results with an improved reliance. In addition, rigorous criteria were adopted for the study selection. One study, which was included in the meta-analysis by van Staa et al (35), was excluded for comparing insulin or sulfonylureas with metformin in combination with other agents, rather than metformin only. In the sensitivity analysis, by separately excluding the study with a high weight (19) or lower quality (25), the results did not materially change, which indicated that the result of overall analysis was stable.

Furthermore, in order to further inspect the stability of the results and find the possible source of statistical heterogeneity, subgroup analysis was performed according to several variables. Each study provided the adjusted HR. All the studies were adjusted for age and gender, but other potential confounders, such as smoking status, body mass index (BMI), dosage of metformin and comorbidity, were not matched in certain enrolled studies, which may cause the material change of the final results. Unadjusted HR was retrieved from three studies $(20,21,26)$ and no significant association was obtained according to the unadjusted HR (RR=0.62; 95\% CI, 0.33-1.18). The magnitude of lung cancer risk reduction was strengthened when compared to sulfonylureas ( $\mathrm{RR}=0.79 ; 95 \% \mathrm{CI}, 0.83-0.9$ ), 
without significant heterogeneity ( $\mathrm{Q}$-value $=2.98, \mathrm{P}=0.085)$, which may be attributed to the decreasing levels of endogenous insulin in metformin users. Different control drugs may partly contribute to the heterogeneity. Four studies evaluated the effect of exposure (duration and dosage) of metformin on the association. Lai et al (20) reported that the HR was reduced to 0.33 among patients who had used metformin for $>3$ years ( $R R=0.33$; 95\% CI, 0.19-0.57), compared to non-users. However, Smiechowski et al (22) found that no interaction was obtained with long-term use of metformin $(\mathrm{RR}=0.90 ; 95 \% \mathrm{CI}, 0.67-1.22)$. As the dose of metformin always increases with increasing duration of use, dose variables can be confounded by duration. Therefore, the duration and dosage of metformin were combined together in the subgroup analysis restricted to long-term use. Although a null result was found ( $\mathrm{RR}=0.89 ; 95 \% \mathrm{CI}, 0.79-1.01)$, this indicated that a trend toward reduction of lung cancer risk was linked to long-term use of metformin. Of note, no interaction was obtained in the analysis stratified by different countries.

Several limitations of the present meta-analysis should be addressed. First, the reliance of the results was weakened by the drawbacks that are inherent to retrospective observational studies, such as possible investigator and recall biases. All the eight studies enrolled were retrospective. Details of metformin dose, duration and other information on potential confounders and risk factors were incomplete, some of which were not fully adjusted in several studies. For example, tobacco use is a well-known risk factor, but only one study evaluated the effect of tobacco use on the lung cancer risk of diabetes patients with metformin therapy (22). Other potentially important clinical covariants, such as BMI, glycemic control, smoking status and lung diseases, were not evaluated as they were only attributed to a few associated studies. Second, the studies were performed in different countries, using different datasets and stratification standards, which may partly contribute to the heterogeneity. For example, the classification of treatment duration was not uniform. Lai et al (20) recognized $>3$ years as long-term use and in another study by Smiechowski et al (22), >1,485 days was classified as long-term use, which may induce a certain effect on the results of the subgroup analysis. The comparator drugs, mainly including insulin and insulin secretagogues, should also be taken into account. The majority compared metformin to a combination of other glucose-lowering agents, rather than a certain agent, which may play an important effect on the association. Only two studies compared metformin with sulfonylureas alone $(19,24)$ and the heterogeneity disappeared in the subgroup analysis comparing with sulfonylureas. Third, the evidence derived from case-control or cohort studies is generally lower compared to from randomized controlled studies. The present meta-analysis was performed based on seven case-control and one cohort study, without any randomized controlled study. OR was treated as approximate $\mathrm{RR}$, which may also influence the final results. Therefore, the results of the meta-analysis should be reviewed with caution.

In conclusion, the present meta-analysis has indicated that the use of metformin significantly decreased the lung cancer risk of patients with T2DM. However, further investigations, particularly randomized controlled trials, are required to confirm the association.

\section{References}

1. Yerrabothala S, Shaaban H, Capo G, Maroules M and Debari VA: The impact of diabetes mellitus on breast cancer outcomes: a single center retrospective study. Pathol Oncol Res 20: 209-214, 2014.

2. Lee JY, Jeon I, Lee JM, Yoon JM and Park SM: Diabetes mellitus as an independent risk factor for lung cancer: a meta-analysis of observational studies. Eur J Cancer 49: 2411-2423, 2013.

3. Wang JY, Chao TT, Lai CC, et al: Risk of colorectal cancer in type 2 diabetic patients: a population-based cohort study. Jpn J Clin Oncol 43: 258-263, 2013.

4. Gupta SP, Mittal A, Jha DK, Pandeya DR and Sathian B: Diabetes mellitus and renal cell carcinoma - a hospital based study from Kathmandu Valley. Asian Pac J Cancer Prev 13: 4963-4965, 2012.

5. Onitilo AA, Stankowski RV, Berg RL, et al: Type 2 diabetes mellitus, glycemic control, and cancer risk. Eur J Cancer Prev 23: 134-140, 2014.

6. Franciosi M, Lucisano G, Lapice E, Strippoli GF, Pellegrini F and Nicolucci A: Metformin therapy and risk of cancer in patients with type 2 diabetes: systematic review. PLoS One 8: e71583, 2013.

7. Lin CC, Yeh HH, Huang WL, et al: Metformin enhances cisplatin cytotoxicity by suppressing signal transducer and activator of transcription-3 activity independently of the liver kinase B1-AMP-activated protein kinase pathway. Am J Respir Cell Mol Biol 49: 241-250, 2013.

8. Han D, Li SJ, Zhu YT, Liu L and Li MX: LKB1/AMPK/mTOR signaling pathway in non-small-cell lung cancer. Asian Pac J Cancer Prev 14: 4033-4039, 2013.

9. Quinn BJ, Dallos M, Kitagawa H, et al: Inhibition of lung tumorigenesis by metformin is associated with decreased plasma IGF-I and diminished receptor tyrosine kinase signaling. Cancer Prev Res (Phila) 6: 801-810, 2013.

10. Kourelis TV and Siegel RD: Metformin and cancer: new applications for an old drug. Med Oncol 29: 1314-1327, 2012.

11. Kato K, Gong J, Iwama H, et al: The antidiabetic drug metformin inhibits gastric cancer cell proliferation in vitro and in vivo. Mol Cancer Ther 11: 549-560, 2012.

12. Storozhuk Y, Hopmans SN, Sanli T, et al: Metformin inhibits growth and enhances radiation response of non-small cell lung cancer (NSCLC) through ATM and AMPK. Br J Cancer 108: 2021-2032, 2013.

13. Kumar S, Meuter A, Thapa P, et al: Metformin intake is associated with better survival in ovarian cancer: a case-control study. Cancer 119: 555-562, 2013.

14. Ferla R, Haspinger E and Surmacz E: Metformin inhibits leptin-induced growth and migration of glioblastoma cells. Oncol Lett 4: 1077-1081, 2012.

15. Kobayashi M, Kato K, Iwama $\mathrm{H}$, et al: Antitumor effect of metformin in esophageal cancer: In vitro study. Int J Oncol 42: 517-524, 2013.

16. Noto H, Goto A, Tsujimoto $\mathrm{T}$ and Noda M: Cancer risk in diabetic patients treated with metformin: a systematic review and meta-analysis. PLoS One 7: e33411, 2012.

17. Lee MS, Hsu CC, Wahlqvist ML, Tsai HN, Chang YH and Huang YC: Type 2 diabetes increases and metformin reduces total, colorectal, liver and pancreatic cancer incidences in Taiwanese: a representative population prospective cohort study of 800,000 individuals. BMC Cancer 11: 20, 2011.

18. Mazzone PJ, Rai H, Beukemann M, Xu M, Jain A and Sasidhar M: The effect of metformin and thiazolidinedione use on lung cancer in diabetics. BMC Cancer 12: 410, 2012.

19. Ruiter R, Visser LE, van Herk-Sukel MP, et al: Lower risk of cancer in patients on metformin in comparison with those on sulfonylurea derivatives: results from a large population-based follow-up study. Diabetes Care 35: 119-124, 2012.

20. Lai SW, Liao KF, Chen PC, Tsai PY, Hsieh DP and Chen CC: Antidiabetes drugs correlate with decreased risk of lung cancer: a population-based observation in Taiwan. Clin Lung Cancer 13: 143-148, 2012.

21. Bodmer M, Becker C, Jick SS and Meier CR: Metformin does not alter the risk of lung cancer: a case-control analysis. Lung Cancer 78: 133-137, 2012

22. Smiechowski BB, Azoulay L, Yin H, Pollak MN and Suissa S: The use of metformin and the incidence of lung cancer in patients with type 2 diabetes. Diabetes Care 36: 124-129, 2013. 
23. Wells GA, Shea B, O'Connell D, et al: The Newcastle-Ottawa Scale (NOS) for assessing the quality of nonrandomised studies in meta-analyses. http://www.ohri.ca/programs/clinical_epidemiology/oxford .asp. Accessed February 5, 2013.

24. Hsieh MC, Lee TC, Cheng SM, Tu ST, Yen MH and Tseng CH: The influence of type 2 diabetes and glucose-lowering therapies on cancer risk in the Taiwanese. Exp Diabetes Res 2012: 413782, 2012.

25. Wang SY, Chuang CS, Muo CH, et al: Metformin and the incidence of cancer in patients with diabetes: a nested case-control study. Diabetes Care 36: e155-e156, 2013.

26. Libby G, Donnelly LA, Donnan PT, Alessi DR, Morris AD and Evans JM: New users of metformin are at low risk of incident cancer: a cohort study among people with type 2 diabetes. Diabetes Care 32: 1620-1625, 2009.

27. Orgel E and Mittelman SD: The links between insulin resistance, diabetes, and cancer. Curr Diab Rep 13: 213-222, 2013.

28. Lemke LB, Rogers AB, Nambiar PR and Fox JG: Obesity and non-insulin-dependent diabetes mellitus in Swiss-Webster mice associated with late-onset hepatocellular carcinoma. J Endocrinol 199: 21-32, 2008

29. Sugiyama T,Nakanishi M,Hoshimoto K, et al: Severely fluctuating blood glucose levels associated with a somatostatin-producing ovarian neuroendocrine tumor. J Clin Endocrinol Metab 97: 3845-3850, 2012.
30. Pisani P: Hyper-insulinaemia and cancer, meta-analyses of epidemiological studies. Arch Physiol Biochem 114: 63-70, 2008.

31. Thakkar B, Aronis KN, Vamvini MT, Shields K and Mantzoros CS: Metformin and sulfonylureas in relation to cancer risk in type II diabetes patients: a meta-analysis using primary data of published studies. Metabolism 62: 922-934, 2013.

32. Chang $\mathrm{CH}$, Lin JW, Wu LC, Lai MS and Chuang LM: Oral insulin secretagogues, insulin, and cancer risk in type 2 diabetes mellitus. J Clin Endocrinol Metab 97: E1170-E1175, 2012.

33. Kao CH, Sun LM, Chen PC, et al: A population-based cohort study in Taiwan - use of insulin sensitizers can decrease cancer risk in diabetic patients? Ann Oncol 24: 523-530, 2013.

34. Colmers IN, Bowker SL and Johnson JA: Thiazolidinedione use and cancer incidence in type 2 diabetes: a systematic review and meta-analysis. Diabetes Metab 38: 475-484, 2012.

35. van Staa TP, Patel D, Gallagher AM and de Bruin ML: Glucose-lowering agents and the patterns of risk for cancer: a study with the General Practice Research Database and secondary care data. Diabetologia 55: 654-665, 2012. 